\title{
Meningkatkan produktivitas dengan bekerja kolaboratif secara remote dengan Google Docs
}

\author{
Danner Sagala \\ Fakultas Pertanian, Universitas Prof. Dr. Hazairin, SH \\ Email: danner_10@unihaz.ac.id
}

\begin{abstract}
Abstrak
Model kerja kolaboratif menjadi salah satu pilihan dalam menyelesaikan persoalan-persoalan dalam kehidupan sehari-hari. Setiap persoalan yang ingin diselesaikan oleh para akademisi/peneliti harus melibatkan beberapa bidang ilmu terkait karena suatu masalah tidak pernah berdiri sendiri. Salah satu contoh yang dapat diberikan untuk penjelasan di atas adalah upaya penyelesaian mengenai produksi kedelai di Indonesia. Suatu teknologi budidaya yang ditemukan oleh seorang peneliti budidaya pertanian (agronomis) harus dianalisa sosial ekonomisnya. Selain itu, pengembangan berikutnya mungkin perlu melibatkan peneliti mekanisasi pertanian dan peneliti teknologi pasca panen. Pada akhirnya, teknologi tersebut dapat digunakan dengan baik di taraf masyarakat. Oleh karena itu, model kerja kolaboratif sangat didorong lembaga-lembaga penyedia dana penelitian. Salah satu contohnya adalah Kementerian Riset, Teknologi dan Pendidikan Tinggi Republik Indonesi. Beberapa skim penelitian yang didanai oleh Kemenristekditi mengharuskan adanya kolaborasi antar bidang ilmu atau kolaborasi antar bidang ilmu akan memberi nilai tambah jika skim tersebut tidak mengharuskan kolaborasi.

Perkembangan ilmu pengetahuan dan teknologi semakin membuat dunia tanpa batas. Semua orang dapat terhubung dengan cepat dan realtime. Seseorang tidak perlu bertemu secara fisik jika ingin bekerja bersama dengan seorang lain atau sekelompok lainnya. Hal ini berbeda dengan pada masa sebelum era digital dewasa ini. Hasil teknologi dapat digunakan untuk mengatasi kendala dalam pemilihan mitra kolaborasi jika mitra yang cocok untuk suatu topik berada jauh dari peneliti utama atau berada pada lembaga yang berbeda. Salah satu buah dari perkembangan teknologi terkini yang dapat dimanfaatkan untuk bekerjasama adalah Google Dokumen (Google Docs).

Aplikasi ini merupakan produk dari Google. Google docs memiliki fitur yang sama dengan aplikasi pengolah kata Word yang merupakan produks Microsoft. Google docs dapat digunakan untuk mengetik dan memformat teks, gambar dan tabel. Kelebihan dari Google docs ini adalah
\end{abstract}


dapat digunakan secara remote atau jarak jauh. Perubahan-perubahan yang dilakukan oleh anggota tim akan langsung tersimpan secara otomatis sehingga pengguna tidak perlu kuatir kehilangan data yang sudah diketik. Setiap perubahan juga tercatat dalam log sehingga dapat diketahui siapa dan apa yang diubah dari dokumen tersebut.

Seseorang yang ingin menggunakan harus memiliki akun google. Google menerapkan sistem akun tunggal untuk semua produk google (one account, all of google). Google docs dapat dibuka di sini jika sudah memiliki akun google https://www.google.com/intl/id/docs/about/. Google docs memastikan kita dapat bekerja dimana saja, kapan saja dan menggunakan alat apa saja (laptop, komputer PC, tablet, dll).

Perkembangan teknologi yang demikian seharusnya linier dengan produktifitas para peneliti.

Extended abstract 